\title{
Swedish Catholicism and Authoritarian Ideologies: Attitudes to Communism, National Socialism, Fascism, and Authoritarian Conservatism in a Swedish Catholic Journal, 1922-1945
}

\author{
Mikael Nilsson \\ Uppsala University \\ mikael.nilsson@hist.uu.se
}

\begin{abstract}
This article investigates the attitude to communism, National Socialism, Fascism, and authoritarian conservatism in the Swedish Catholic Church's journal Credo from 1922 to 1945 . The comparative approach has made it possible to see how the journal distinguished between the various forms of authoritarian ideologies in Europe during this period. The article shows that the Catholic Church in Sweden took a very negative view of communism (the Soviet Union and the Spanish Republic) and strongly condemned it throughout the period, while it took a largely very positive stance towards Fascism (Italy) and Authoritarian Conservativism (Spain and Portugal). In the case of National Socialism (Nazi Germany) the attitude was more diverse. Credo was largely negative towards National Socialism but only because it was thought to threaten Catholics and Catholicism in Germany. However, Credo never criticized discrimination and genocidal violence against the Jews.
\end{abstract}

\section{Keywords}

Fascism - Catholicism - National Socialism - communism - Sweden - authoritarianism - Francisco Franco (1892-1975) - António de Oliveira Salazar (1889-1970) 
The Catholic Church is one of the most influential and endurable institutions in human history. About 1.18 billion people are confessing Catholics today and the faith is represented on all continents around the globe. ${ }^{1}$ It is also an institution that stirs up feelings and everyone seems to have an opinion about it, good or bad. The Church's relationship to Nazi Germany and Pope Pius XII's silence during the Second World War about the Holocaust has spurred a great number of both critical and apologetic accounts. ${ }^{2}$

Research concerning the Christian churches, their relationship with the totalitarian regimes in Europe, and their attitude towards anti-Semitism in the twentieth century has produced many books and articles during the last two decades, both in English and German (and other languages as well). So many, in fact, that it would be impossible to list them all. ${ }^{3}$ But this research has been unevenly spread. Research regarding both the Protestant and Catholic churches'

1 'Number of Catholics in the world grows by $15 \mathrm{~m}$. in a year,' Catholic Herald, February 21, 2011, accessed March 30, 2016, http://www.catholicherald.co.uk/news/2011/02/21/ number-of-catholics-in-the-world-grows-by-15m-in-a-year/.

2 Peter Godman, Hitler and the Vatican: Inside the Secret Archives that Reveal the New Story of the Nazis and the Church (New York: Free Press, 2004); Ronald J. Rychlak, Hitler, the War, and the Pope (Huntington: Our Sunday Visitor, 200o); Gerard Noel, Pius XII: The hound of Hitler (London: Continuum, 2008); Michael Phayer, The Catholic Church and the Holocaust, 1930-1965 (Bloomington: Indiana University Press, 2000); Joseph Buttom and David G. Dalin, ed., The Pius War: Responses to the Critics of Pius XII (Lanham: Lexington Books, 2004); José M. Sánchez, Pius XII and the Holocaust: Understanding the Controversy (Washington D.C.: Catholic University of America Press, 2002); Carol Rittner and John K. Roth, ed., Pope Pius XII and the Holocaust (London: Leicester University Press, 2002).

3 For some of the more recent titles, see: Kevin P. Spicer, ed., Antisemitism, Christian Ambivalence, and the Holocaust (Bloomington: Indiana University Press, 2007); Kevin P. Spicer, Hitler's Priests: Catholic Clergy and National Socialism (DeKalb: Northern Illinois University Press, 2008); Richard Steigmann-Gall, The Holy Reich: Nazi Conceptions of Christianity, 1919-1945 (Cambridge: Cambridge University Press, 2003); Derek Hastings, Catholicism and the Roots of Nazism: Religious Identity \& National Socialism (Oxford: Oxford University Press, 2010); Beth A. Greich-Polelle, Bishop von Galen: German Catholicism and National Socialism (New Haven: Yale University Press, 2002); Frank J. Coppa, ed., Controversial Concordats: The Vatican's Relations with Napoleon, Mussolini, and Hitler (Washington, D.C.: The Catholic University of America Press, 1999); Susan Zuccotti, Under His Very Windows: The Vatican and the Holocaust in Italy (New Haven: Yale University Press, 200o); Doris L. Bergen, Twisted Cross: The German Christian Movement in the Third Reich (Chapel Hill: The University of North Carolina Press, 1996); Susannah Heschel, The Aryan Jesus: Christian Theologians and the Bible in Nazi Germany (Princeton: Pinceton University Press, 2008); Gerhard Beiser and Francesca Piombo, Der Heilige Stuhl und Hitlers Deutschland: Die faszination des Totalitären (München: Deutsche Verlags-Anstalt, 2004); Daniel Jonah Goldhagen, A moral Reckoning: The Role of the Catholic Church in the Holocaust and its Unfulfilled Duty of Repair (London Little, Brown, 2002); Christoph Strohm, Die Kirchen im Dritten Reich (Munich: Verlag C.H.Beck, 2011); 
relations with Nazism is immense; the research investigating their dealings with Italian Fascism less so; and the churches' attitude towards communism has received far less attention. In Sweden too there has been an increasing volume of books and articles about this subject in recent years. This research has concentrated on Nazi-sympathising priests and churches. ${ }^{4}$ But this research has focused solely on the Protestant churches, which is not strange considering that the Catholic Church has been a marginal phenomenon in Sweden since the faith was outlawed after 1593 (and remained so until 186o). The last remnants of discriminatory laws were not removed until $195^{2}$ when the Freedom of Religion Law took effect. ${ }^{5}$

Reliable figures for the number of Catholics in Sweden during this period are actually very hard to come by. Official statistics up to 1935 only list the number of 'Dissidents and Foreign Believers' until 1920, and after that only for the year 1930 until the category disappears all together in 1951 when the law of freedom of religion apparently made such statistics problematic. We can only say that there were 3,425 Roman Catholics and 281 Greek Catholics in Sweden in 1920 , and by the end of 1930 this number had increased somewhat to $4,818 .{ }^{6}$ This was out of a total population of 6,141,571 by $1930 .{ }^{7}$

Only one monograph has been published on the subject of Nazism and the Churches in Sweden, and it does not mention the Catholic journals. ${ }^{8}$ As a consequence we know very little about how the Catholic Church in Sweden viewed fascism or communism or how they were described to the readers of their journals. Despite the fact that the Catholic Church was so small in Sweden there were two Catholic journals in print; one was called Hemmet \& Helgedomen [The Home \& The Sanctuary] and the other Credo. It is the latter that will be studied in this article.

Thomas Brechenmacher and Harry Oelke, ed., Die Kirchen und die Verbrechen im nationalsozialistischen Staat (Göttingen: Wallstein Verlag, 2011).

4 The Swedish research is summarized in: Klas Åmark, Att bo granne med ondskan: Sveriges förhållande till nazismen, Nazityskland och Förintelsen [To Live Next Door to Evil: Sweden's Relationship to Nazism, Nazi Germany, and the Holocaust] (Stockholm: Albert Bonniers Förlag, 2011), 331-356.

5 Yvonne Maria Werner, 'Katolicism och religionsfrihet: Den svenska religionsfrihetslagen $5^{0}$ år' [Catholicism and Freedom of Religion: The Swedish Freedom of Religion Law 50 Years], Signum 2002, no. 9, accessed August 8, 2012, http://www.signum.se/archive/read.php?id=935.

6 Statistisk Årsbok för Sverige [Statistical Year Book for Sweden] 22 (1935) and 23 (1936): 24 and 24 respectively.

7 Statistisk Årsbok för Sverige [Statistical Year Book for Sweden] 18 (1931): 4.

8 Lars Gunnarsson, Kyrkan, nazismen och demokratin: Åsiktsbildning kring svensk kyrklighet 1919-1945 [The Church, Nazism, and Democracy: Opinion-Making in Swedish Churches, 1919-1945] (Stockholm: Acta Universitatis Stockholmiensis, 1995). 
Internationally, only a few articles have been published that deal with the attitude of Catholic journals to the totalitarian ideologies of the twentieth century. One article, written by Frederick K. Wentz, was published in the American journal Church History in 1962, and in it Wentz investigates three Catholic journals and their reactions to National Socialism between 1933 and 1937 (but attitudes to communism and Italian Fascism are also mentioned). The most important results in his investigation were that communism was seen as the largest threat by far to the Catholic Church and the Catholic faith. American Catholics, according to Wentz, on the other hand, mostly saw Fascism as something positive. Nazism, lastly, was criticized loudly from about 1935 when it became clear that the Hitler regime was fighting the Church's influence in Germany, but was tempered somewhat by the fact that Nazism's anti-Bolshevik crusade was shared by the Church. Confidence for the National Socialist government remained throughout $1937 .^{9}$

This study utilizes terminology that needs a little explaining. The terms National Socialism (or Nazism) and communism are pretty straightforward and we do not really need to dwell on them here except to say that National Socialism is used to describe the Hitler regime in Germany and communism is used to describe the ideological systems in the Soviet Union under Stalin and Republican Spain. Whether the Spanish republic was really communist or not is not relevant to our discussion below; the important thing is that Credo thought it was and used this term to signify it. Fascism, it needs hardly be added, is not as straightforward. What remains uncontroversial though is that Mussolini's Italy was a Fascist state. Whether Spain and Portugal were fascist is far more contentious. ${ }^{10}$ Regarding the term totalitarianism suffice it to say that I use it here to denote any authoritarian ideology that aspired to subordinate all of society and the individual under its reign (the use of the verb 'aspired' is correct because no regime was really powerful enough to fully realize this aim).

It is perhaps not obvious why a study of Credo, a small and insignificant Swedish Catholic journal, is necessary. Even though Credo and Catholicism were marginal entities during this period, the journal was nonetheless a

Frederick K. Wentz, 'American Catholic Periodicals React to Nazism,' Church History 31, no. 4 (1962): 400-420.

10 For an introduction to the research and debates about the nature of fascism, see: Roger Griffin, Modernism and Fascism: The sense of a Beginning under Mussolini and Hitler (Basingstoke: Palgrave Macmillan, 2007); Robert O. Paxton, The Anatomy of Fascism (London: Allen Lane, 2004); Roger Griffin, Werner Loh and Andreas Umland, ed., Fascism Past and Present, West and East: An International Debate on Concepts and Cases in the Comparative Study of the Extreme Right (Stuttgart: Ibidem-Verlag, 2006). 
central Catholic voice in Sweden and thus its attitude towards the authoritarian ideologies in Europe in the twentieth century is of interest to historians. One issue that has been central to research in this area is the Catholic Church and its attitude towards anti-Semitism more generally and the Shoa, or the Holocaust, in particular. Any article that investigates the Swedish Catholic Church's stance with regard to the totalitarian ideologies can obviously not avoid these issues. What is also interesting about this investigation is that by studying a Catholic journal it comes much closer to the attitudes and feelings of ordinary Swedish Catholics than a study of papal speeches or intra-Church communication would. As such it has the potential to contribute new and important knowledge about the type of views that ordinary Catholics were thought to have.

This article asks the following questions: What image of these ideologies and regimes did Credo purvey to its readers? What was the journal's attitude towards anti-Semitism and the discrimination, deportation, and mass murder of the European Jews before and during the Second World War? The article is structured in three parts: first it investigates the attitude towards communism in the Soviet Union and Republican Spain; then its attitude towards Nazi Germany; and finally its attitude towards Mussolini's Italy and Salazar's Portugal.

\section{Credo and Communism}

The Catholic Church's hatred of communism is well known. It is, however, of interest to see how this well-known attitude was expressed in the Swedish Catholic journal. What image of this ideology was given to members of the Swedish Catholic Church, or at least the readers of Credo? Already in November 1920, i.e. in the first year of publication, we find an article designating Poland 'Rome's Sentry Towards the East.'11 Interestingly, the author meant that the Russian Orthodox Church was 'a spiritual mother to bolshevism' because it was both 'despotic and anarchic.' It was because of this 'spiritual regime' that 'the Russian people had developed the indolent character with a deep penchant for melancholy, which contrasted so brightly against the active and happy Polish mind'.12 The view that bolshevism was a kind of heretical religion was something that Credo would return to on other occasions, e.g. in February

\footnotetext{
11 'Roms vaktpost mot Öster: Polens katolska mission,' Credo: Katolsk Tidskrift 1, no. 11 (November 1920): 188.

12 Ibid., 190.
} 
1924 when it was declared that the mother religion in the Soviet Union was, at present, 'collectivism. ${ }^{13}$

In June 1922 we find an example of the hostility towards both communists and Jews in Credo in an article about the Church's position in Hungary. The author, Ladislaus von Szendy, explained to readers that 'the last 50 years of Hungary's history has meant unequivocal progress for the Jewish-radical elements.' Szendy also complained about the fact that recent converts to the Catholic faith were all too weak in their faith and insufficiently Catholic in practice. They took part 'in all Christian events but on the Sundays they don't show themselves at mass' and they may 'have become members in one or another Christian or anti-Semitic organization (e.g. The Awakening Hungary) but one can never see them on a communion bench or in a confession chair. ${ }^{14}$ For Szendy being a member of an anti-Semitic organization was part of being a good Catholic. Similar anti-Semitic views were expressed on many other occasions in Credo. For example, in June 1926 it was reported that 'the Jew-problem is particularly urgent in Hungary, where at the moment there are 480,000 Israelites, who naturally have made sure to amass a disproportionate influence.'15

The anti-Semitism in Credo also creeps out in an article about the Soviet Union where the author writes that 'during an inspection of the Catholic Churches the commissars, who were mostly Jews, acted with frivolous insolence.16 Included also was an anecdote about the archbishop of Smolensk holding an emotional speech in front of the execution squad that moved even the red soldiers to such a degree that they lowered their rifles 'as if gripped by a sudden piety' when 'a Jew, who was present in their ranks, shot the honourable bishop.' ${ }^{17}$ Stories like these of course served both to confirm, and to perpetuate and deepen, the Christian view of the Jews as the killers of Christ and generally untrustworthy figures. Yet another anecdote told of a church in Gatuczyn in Poland where 'the church door [was] broken down by a Jewish commissar, who carried away all gold and silver pots'.18 The ethnicity of the commissar is obviously not relevant but serves only to confirm Catholic antiSemitic prejudices.

\footnotetext{
13 'Från Credos torn,' Credo: Katolsk Tidskrift 5, no. 2 (February 1924): 44.

14 Ladislaus von Szendy, 'Katolska KyrkaninUngern,' Credo: Katolsk Tidskrift 3, no. 6 (June 1922): 147, 149 .

15 'Från Credos torn,' Credo: Katolsk Tidskrift 7, no. 6 (June 1926): 170.

16 'Brev från Ryssland,' Credo: Katolsk Tidskrift 4, no. 4 (April 1923): 91.

17 Ibid., 91-92.

18 Ibid., 93 .
} 
In the editorial section in the same issue we find a horror story that deserves to be quoted in full:

The hatred of religion in Soviet-Russia has begun to take on the most horrible and grotesque forms. All the country's Catholic Churches are closed up, and it is forbidden to read mass in private houses. In Moscow the Russian Christmas has been celebrated by the reds through a large open-air spectacle, at which pictures of the Lord our Father and all the religious founders were torched. Similar events have taken place in Petrograd. According to a suggestion for a new communist calendar a feast to remember the 'dethroning of God' should replace the Christian Christmas. Later, in several Russian cities according to Ruskulta, and in the presence of various communist celebrities and red soldiers God had 'been put on trial and sentenced'. ${ }^{19}$ [Italics in original.]

There can be no doubt as to what image of communism the readers of Credo received, or that this image was radically different to the one that was purveyed of Fascism or Nazism. From the criticism it is also obvious why: the Nazi and Fascist regimes never committed nearly as many atrocities against the Catholic Church. The Soviet Union was even called 'the land of religious persecution' by $C r e d o .^{20}$ The above fits with how the American Catholic journals described communism to their readers, and as in Credo the absolute majority of the articles that condemned communism referred to the Soviet Union. ${ }^{21}$

In 1931 the Spanish republic was established and in Credo this was immediately identified as being a great future test for Catholics in Spain. Articles proclaiming the evil of the republic become more and more common in Credo. In February 1932 it was stated that the 'culture struggle' in Spain 'is a struggle between anti-Catholic powers and the Catholic Church' and that the republican government in Madrid belonged to 'the powers of darkness.'22 From Spain came reports of 'anti-religious excesses of the most horrid kind' where 'Churches were ignited and precious monastic libraries were burned by lynch mobs, instigated by Moscow and their Spanish stable brothers.'23 The Pope

19 'Från Credos torn,' Credo: Katolsk Tidskrift 4, no. 4 (April 1923): 105.

20 Gustaf Armfelt, 'Religionsförföljelsens rike,' Credo: Katolsk Tidskrift 5, no. 4 (April 1924): 79 .

21 Wentz, 'American Catholic Periodicals,' 406.

22 'Från Credos torn,' Credo: Katolsk Tidskrift 13, no. 2 (February 1932): 54.

23 Gustaf Armfelt, 'Kyrkokrönika från 1931,' Credo: Katolsk Tidskrift 13, no. 4 (April 1932): 107. 
issued a harsh encyclical 'against the persecution of the Catholic Church in Spain' in June 1933, which was referenced in Credo. ${ }^{24}$

Communism was once again severely criticized in a chronicle of 1935 that was published in April 1936, ${ }^{25}$ and also in Credo's March 1937 issue where the reader was informed that the majority of the higher priests in the Soviet Union had 'either been murdered, or through gruesome prison life and forced labor, met with certain death.' Moreover, it was said that 'relentless, ruthless struggle against religion, aiming for its total eradication' was 'the soul of bolshevism.' In the Stalinist constitution 'satanic measures were being prepared in order to spread the plague of godlessness to all layers of the population, not least to the children.'26 The language was obviously marked by desperation and it is clear that when one compares the words and expressions used about communism with the ones used about Nazism, the godlessness of bolshevism and communism was seen as a much bigger and potent threat to Christianity than Nazism could ever be.

This difference was also clearly demonstrated in an editorial about the Spanish Civil War. In this article it was pointed out that the war was a battle between 'on the one side, the champions of the ideals, which have sprung forth from Spain's old traditions and old history; and on the other side stands warriors whose only goal is not victory over the enemy, but the destruction of all values of the national civilization. ${ }^{27}$ Credo celebrated the Spanish nationalists and it let the readers understand that:

The national movement, which in its struggle against Marxism has appeared stronger and stronger, has, the Cardinal Primatesta stresses, had a strong basis in its religion. On all fronts the national troops have celebrated the mass sacrifice, thousands of young soldiers have confessed and received the Holy Communion, and in the camps they have prayed the rosary together. Their dedication to their faith has been just as great as the religious eagerness of those at home. In this way religion has given the fighters for the motherland new courage and strength. ${ }^{28}$

\footnotetext{
24 'Från Credos torn,' Credo: Katolsk Tidskrift 14, no. 9 (1933): 221-223.

25 Gustaf Armfelt, 'Kyrkokrönika för år 1935,' Credo: Katolsk Tidskrift 17, no. 4 (April 1936): 86-87.

26 'Från Credos torn,' Credo: Katolsk Tidskrift 18, no. 3 (March 1937): 71.

27 Ibid., 71-72.

28 Ibid., 72 .
} 
Note that the atrocities of the nationalists were not mentioned in Credo's article. There was no comment about the fact that the religious fervour also led to the slaughter of thousands of innocent people - or that the nationalists' hatred of communism was at least as strong as the latter's hatred of religion. The republic's crimes were mentioned, however, and it was stated that 'thousands of priests and monastic inhabitants have been murdered' during the revolution. Christ and Antichrist were struggling against each other on Spanish soil, according to Credo. ${ }^{29}$ In November 1937 Credo referenced a letter written by a number of Spanish bishops where, e.g., it was said that: 'The national movement has fortified the love of the nation and promoted the true love for ones neighbor. It has brought back order and calmness; everywhere the Christian life has blossomed once again. What thus has been created within the national zone ensures a righteous and peaceful regime in the future. ${ }^{30}$

Between these articles Credo managed to fit in even more scathing criticism of the republic:

In Spain the red reign of terror is even worse than the Communists in Finland in 1918. For there the 'whites', heavily supported by a German fleet and a German troop landing party ... , managed to quell the red terrorists relatively soon and end their bloody ravages. In Spain, however, the red extremists were cherished .... Under the pressure from the extremists thousands of political prisoners, even hardened criminals, were set free, and the consequences were soon obvious. The acts of violence from 1931 were repeated; churches, monasteries, Catholic institutions, editorial offices were burned and pillaged, and the number of murders were legion. ${ }^{31}$

Because of this, said Credo, 'General Franco acted correctly when he declared war on hell before hell declared war on him.'32 The republic was constantly condemned as criminal while the nationalists just as often were portrayed as exemplary Christians. ${ }^{33}$ The Spanish bishops stressed 'that righteousness and peace' could be returned to Spain 'only through a victory for the national movement.'34

\footnotetext{
29 Ibid.

30 'Från Credos torn,' Credo: Katolsk Tidskrift 18, no. 11 (November 1937): 257.

31 Gustaf Armfelt, 'Kyrkokrönika för år 1936,' Credo: Katolsk Tidskrift 18, no. 5 (May 1937): 102.

32 Ibid., 103.

33 'Från Credos torn,' Credo: Katolsk Tidskrift 18, no. 11 (November 1937): 257.

34 Ibid., 258.
} 
The bishops' wishes would soon be fulfilled. Catholic writer Gustaf Armfelt glorified Franco and the nationalists for their piety. The Catholics in Spain had 'for years endured bloody persecution from the reds, cheered on by Bolshevik commissars from Moscow', but after Franco's victory there was hope for the Church in Spain, he wrote, because 'a glorious restoration work was going on in Franco-Spain in both the earthly and the spiritual realm, and Christian schools were reinstated, led by spiritual orders'. ${ }^{35}$ Credo was not the only Catholic journal to celebrate Franco as the saviour of Spain's religious life; the American Catholics took exactly the same position. ${ }^{36}$

Interestingly, one can see a marked decrease in the criticism of the Soviet Union from $1941 \mathrm{on}$. If this had anything to do with the fact that the U.s.s.R. was now allied with the Western powers against Nazi Germany is not possible to say, but the coincidence in time surely points in that direction. In December 1941, however, one critical article was published. It saw Stalin's closer relationship with the Russian Orthodox Church as an act to appease the Soviet Union's new allies and to keep the Soviet people together rather than an honest suspension of religious persecution. An investigation of what Credo wrote about Soviet communism after the end of the Second World War (at least up to 1955) shows that the condemnations were toned down even more. The graphic descriptions of the communists' crimes against the Church's representatives melted away and were replaced by a more careful, and to some degree nuanced, criticism. It is also worth noting that the anti-Semitic content of that critique disappeared completely after 1945 . What we see here is a very clear change in Credo's attitude over time, a change no doubt affected by the Holocaust. The journal thus followed the general shift in opinion towards the Jews in the aftermath of the war. On the other hand, it is also a fact that the Holocaust, or the Jews' situation during the war in general, was not awarded one single article in Credo during the decade following the fall of the Third Reich. Moreover, there was not a trace of self-criticism on Credo's part regarding the Church's silence about the Holocaust and the persecution of the Jews in Nazi Germany in the 1930s and 1940s.

\section{Credo and National Socialism}

Credo's attitude to Nazism was characterized by condemnation of this ideology's anti-Catholicism, not its anti-Semitism. Before Hitler came to power in

35 Gustaf Armfelt, 'Kyrkokrönika för år 1938,' Credo: Katolsk Tidskrift 20, no. 6 (June 1939): 186-188.

Wentz, 'American Catholic Periodicals,' 412. 
1933, the number of articles concerning National Socialism were limited. In one article, entitled 'A danger to Christianity and world peace', written in September 1932, there was an effervescent description of how a march undertaken by a Catholic youth organization in Essen was broken up by violent Nazi sympathizers. The article then quoted both Hitler's speeches and Alfred Rosenberg's Der Mythus des 20. Jahrhunderts (as well as the newspaper Der Völkischer Beobachter that was edited by the latter) in order to reveal National Socialism's hostile attitude towards Catholicism. Moreover, it referred to the German bishops' recent condemnation of this ideology where it had been said that 'a Catholic cannot possibly be a faithful son of the Church and a member of the National Socialist Party simultaneously'37 These were truly serious words, but also important to remember when we read what Credo would later write about Hitler's Germany after the German bishops had changed their opinion on this matter, i.e. regarding the compatibility between Catholicism and Nazism.

In July 1933 Credo told its readers about the letter that Hitler had sent to Cardinal Bertram of Breslau, Chairman of the Fulda Bishops' Conference, in which Hitler had promised that Catholic institutions would be left in peace as long as they refrained from hostile political acts against the new government. Furthermore, Hitler had stated that the new government considered the Catholic Church a valuable ally in the fight 'against godlessness, against bolshevism, against vice and love of pleasure. ${ }^{38}$ The main problem with the Nazi regime was thus its tendencies to harass Catholics, not its anti-Semitism. Whenever Nazism's race creed was addressed it was only when it was thought to compete with Christianity.

The only occasion when Credo mentioned anything about the persecution of Jews in Germany was when it complained about the world not protesting nearly as strongly against crimes committed by the Nazi regime against Catholics. In a review of an article in The Month with the headline 'A Memento for Catholics' Credo wrote that 'the dispersed people' (i.e. the Jews) were apparently organized enough to rally world opinion to its cause. The whole thing was 'an admirable example of racial and religious solidarity', according to $\mathrm{Cre}$ $d o$, and added that they did not consider this solidarity uncalled for and that the Catholics did not begrudge 'the Jews this sympathy', which the German attack had awakened within Christian circles. The Nazis' actions had, it was said, made life in Germany 'impossible for every Jew with self-esteem.' But one still had to ask, said Credo, how it could be that the attacks against Catholics

Gustaf Armfelt, 'En fara för kristenheten och världsfreden,' Credo: Katolsk Tidskrift 13, no. 9 (September 1932): 240-242.

38 'Från Credos torn,' Credo: Katolsk Tidskrift 14, no. 7 (July 1933): 171. 
in France, Mexico, and Spain 'had never produced even the smallest hint of protest. ${ }^{\prime 39}$ This indignation, including the idea that the sympathy with the Jews that had been expressed was some kind of propaganda triumph for the Jews, was something that also characterized the reaction of American Catholic journals to reports about persecutions of Jews in Germany. ${ }^{40}$ That the insinuation that the Jews somehow organized the reaction of world opinion to the persecution of Jews in Germany was in itself an anti-Semitic trope, i.e. that the Jews were extremely well organized and powerful.

One must of course remember that when this article was published, in July 1933, the regime's persecution of Jews had not yet reached the terrible levels it would do later. It would therefore be wrong to judge Credo for something that had not yet happened. Even so, Nazism's anti-Semitism was a well-known fact already. Nazis at the local level, even before Hitler came to power, took every chance to beat up Jews (and anyone who was unfortunate enough to look like a Jew). The attacks that the article referred to had occurred in the aftermath of the elections in March 1933 when NSDAP organized a major boycott of Jewish businesses, as well as the law of 7 April 1933, which initiated the purging of Jewish state employees. From this moment on, writes Robert Gellately in Backing Hitler, it was undoubtedly known that the government's policy was now anti-Semitism. ${ }^{41}$ This is also confirmed by studies of Swedish newspapers that followed the developments in Germany from March $1933 .{ }^{42}$

But there was also a broader criticism of the actions of the Hitler regime. Credo for example criticized National Socialism's 'deification of race', and argued that repression of the rights of the individual, exaggerated nationalism and 'antisemitism [which] was realized in the form of violent or more refined persecution' was not a return to a state similar to the Middle Ages, as some had said. On the contrary, the article argued, the Middle Ages was characterized by an ideal where all men belonged to the Catholic Church and thus was one

39 Ibid., 172.

40 Wentz, 'American Catholic Periodicals', 402.

41 That which the Jews in Germany had to endure from 1932 up until this article was written is portrayed in: Robert Gellately, Backing Hitler: Consent \& Coercion in Nazi Germany (Oxford: Oxford University Press, 2001), 24-29. It needs to be said that parts of the German population opposed the boycott, and Gellately underlines that it was especially Catholics that expressed their sympathy (perhaps because of their own somewhat precarious situation). Despite this, however, the support for the regime was so strong by the end of 1933 that the government entertained the idea of getting rid of the Gestapo, Ibid., 31.

Ingvar Svanberg and Mattias Tydén, Sverige och förintelsen:Debatt och dokument om Europas judar 1933-1945 [Sweden and the Holocaust: Debate and Documents About Europe's Jews, 1933-1945] (Stockholm: Dialogos Förlag, 2005), 75-81. 
big family. This Catholic ideal was characterized by 'a strong universalism', it was said. ${ }^{43}$ Unfortunately, besides being an obvious case of historical romanticism (if not outright revisionism) the article also seemed to imply that antiSemitism was all right as long as it did not express itself in the form of violent persecution.

The situation in Hitler's Germany was once again addressed by Gustaf Armfelt in April 1936. Armfelt said that while godlessness was the problem in the Soviet Union, Neo-Hedonism was causing the problems on German soil. National Socialism, according to him, was a new religion that 'constructs myths of race and blood', something which meant 'an upheaval against the first commandment. ${ }^{\prime 44}$ Armfelt noted that the concordat that had been signed three years earlier guaranteed the Church rights in Germany but he simultaneously wrote that there were daily reports of 'attacks against the Christian religion from the German Neo-Hedonists'; Catholic organizations and publishers were persecuted and priests and laymen were arrested. Moreover, Armfelt wrote that the measures against the Catholics had come more or less on the anniversary of 'the horrible massacres in 1934' [i.e. the Night of the Long Knives] when Catholic leaders had also been murdered. ${ }^{45}$ Once again it was the Nazis' crimes against the Church that occupied Armfelt. Violence against Jews and communists in Germany was never mentioned; and by that time it was mostly communists that were arrested en masse and put in the relatively recently opened concentration camps. ${ }^{46}$

It has repeatedly been argued that Pius XI's encyclical from 1937 entitled 'Mit brennender Sorge' utters an unambiguous condemnation of the Nazis' persecution of the Jews in Germany, but these arguments have also been quite effectively disproven by researchers. ${ }^{47}$ However, it is interesting to see how this encyclical was interpreted by Credo, and what parts of it the journal thought important to relate to its readers, i.e. Swedish Catholics. Selected parts

43 'Medeltid,' Credo: Katolsk Tidskrift 14, no. 8 (August 1933): 179.

44 Gustaf Armfelt, 'Kyrkokrönika för år 1935,' 87.

45 Ibid., 88.

46 Most of the about one hundred thousand people that were sent to the camps during 1933 had some connection to the communist party. The same was true for 1934. For more about this, see: Gellately, Backing Hitler, 52, 58-59. But considering Credo's attitude towards communism it does perhaps not come as a surprise that it did not protest persecution of these people. The same could probably be said about the Jews.

47 Susan Zuccotti, 'Pope Pius XII and the Rescue of Jews during the Holocaust: Examining Commonly Accepted Assertions,' in Pope Pius XII and the Holocaust, ed. Carol Rittner and John K. Roth (London: Leicester University Press, 2002), 205-220. 
of the encyclical were published in Credo in August 1937 wholly without comment. There was nothing about Nazi persecutions of Jews in those selected paragraphs. ${ }^{48}$ What did get published on the same editorial pages, however, was a protest from Germany's bishops against the on-going vice trials against Catholic priests and nuns. Under the tenth and last point one even finds an anti-Semitic attack that stated that this tactic on the Nazi regime's part only strengthened the Church's enemies and turned the people against the regime: 'The Church's enemies shall also rejoice and - like the Jews over Judas' treason, over Peter's denial and the other apostles' cowardice - wrench their Pharisaic hands in a holier than thou manner.'49

We have to wait until February 1938 for a review of the Pope's message in 'Mit brennender Sorge' in Credo, and on this instance too any condemnation of the persecution of the Jews is conspicuously absent. ${ }^{50}$ One could perhaps argue that the persecution of the Jews had not reached a level that would give Credo a reason to judge them as more serious than what had happened to the Catholics in Germany. That argument, although hardly a tenable one, would not be possible to maintain after the Kristall Nacht on 9-10 November 1938. But the murders, violent beatings, vandalizing, and harassments of that terrible night were never mentioned by Credo either.

Adolf Hitler was criticized personally on only one occasion, and that was for the annexation of Austria, the so-called Anschlu $\beta$, a country that was described as an exemplary Catholic nation. The Austrian statesman Karl Lueger was also hailed, and his politics was said to have been 'carried and to have been animated by Christian, by Catholic principles. ${ }^{51}$ This is quite a remarkable statement considering that Lueger was a well-known and convinced antiSemite, and a Catholic one at that. ${ }^{52}$ This once again points to the ambiguous message that was conferred on Credo's readers; on the one hand (but very seldom) anti-Semitism was a bad thing, and on the other hand a well-known anti-Semite (who had even inspired Hitler during his time in Vienna) could be hailed for his exemplary Catholic and Christian character. What the readers of Credo should make of all of this, and how they were supposed to be able come to the right conclusion given the mixed messages given to them, is anyone's guess.

\footnotetext{
48 'Mit brennender Sorge,' Credo: Katolsk Tidskrift 18, no 7-8 (July-August 1937): 181-183.

49 'Från Credos torn,' Credo: Katolsk Tidskrift 18, no. 7-8 (July-August 1937): 185.

5o 'Med brännande ängslan,' Credo: Katolsk Tidskrift 19, no. 2 (February 1938): $25^{-27}$.

$5^{1} \quad$ Gustaf Armfelt, 'Kyrkokrönika för år 1938,' Credo: Katolsk Tidskrift 20, no. 6 (June1939): 182.

$5^{2}$ Hastings, Catholisism and the Roots of Nazism, 24-25; Friedrich Heer, Der Glaube des Adolf Hitler: Anatomie einer politischen Religiosität (München: Bechtle Verlag, 1968), 77-79.
} 
In an article directed against totalitarian Germany and Soviet Union in January 1940 the Nazi will to raise race to the highest norm in society was criticized, and the hope was even articulated that the Ribbentrop-Molotov Pact would be suspended and that Germany 'put itself in the forefront of a Crusade against the modern Turk-threat, that the threat from the East means.' The writer, however, did not believe that there was much hope of this happening. The article also pointed out that this was the 'Age of Totalitarianism' and that while the author disavowed 'the totalitarian ideologies' argued for a Catholic totality ideal. ${ }^{53}$ It would only be one and a half years before the Pact between Germany and the Soviet Union was suspended when Hitler's troops attacked the Soviet Union on 22 June 1941. Ironically, the invasion was named after the German crusader Fredrik Barbarossa. Thus, the author's hopes seem to have been fulfilled.

From 1941 on, criticism of totalitarianism, no matter in what shape or form, became rarer in Credo. The journal went through a transformation at the same time and was only published quarterly from that point on. There were no more chronicles of events during the past year and Gustaf Armfelt seems to have stopped writing for Credo on a regular basis even though he still a member of the editorial board. In the March issue that year Credo instead published an article that stated that 'the Holy See cannot take the side of any system.' The Pope's concern about all Christians was heavily underlined, and 'especially poignant' was, according to Credo, the Pope's words 'to all those who suffered because of their faith.' The Jews were not included in that group, however, which was made evident by the Pope talking specifically about 'its priests and believers. ${ }^{54}$ The Jewish religion does not have priests, but rabbis.

A very, in this context, interesting article was published in December 1941 and referred to a pastoral letter written by German bishops in which the anti-Christian policies of the Hitler regime at home was contrasted to the God-fearing German army, the Wehrmacht. It was stressed that while prayer and crucifixes were banned in German schools the Army leadership increased the number of ministers in the field in order to enhance the soldiers' pastoral care, and furthermore that it had been decided that a cross should be put on every soldier grave. After that the bishops mentioned a letter from a German

53 P.J.A. Menzinger, 'Den totalitære stat,' Credo: Katolsk Tidskrift 21, no. 1 (January 1940): 27-30, quote on 30 .

54 P. Pilgrim, 'Vatikanen och neutraliteten,' Credo: Katolsk Tidskrift 22, no. 2 (June 1941): 61-64. 
soldier that made evident 'how the power of prayer strengthened them ${ }^{\prime 55}$ and the bishops asked rhetorically: 'If the people not already in their youth, primarily in school are hold to prayer, how can they then later in life's struggles, especially as soldiers, gain strength from the prayer to fulfil their duties towards the Fatherland?'56

The bishops did not seem to realize the connection between the horrible things that were happening in Europe at that time and the acts of these Christian soldiers, who had all grown up in a Germany with prayers and crucifixes in school. Apparently, too, the bishops did not feel that the soldiers' Christian faith meant that they had any responsibility to protest against the regime; instead they should loyally serve their country and even gain more strength from their prayers in doing their duty. Credo stressed that the main part of the leading Nazis confessed 'a positive Christianity', and that it 'would be ridiculous... to call the National Socialists Neo-Hedonists' since they were 'believers in God but not believers in Christ.' Furthermore, it was said that the leadership of the Wehrmacht were positive towards Christianity, and that good and able officers could only be recruited from 'the Conservative and noble circles that, for the most part, were oriented towards the Church. ${ }^{57}$ With unconcealed pride it was stated that when a soldier was arrested and put in his cell 'a choice of reading was given him, either the Bible or Mein Kampf.' Almost always is the Bible preferred! One often sees soldiers in the Churches, but seldom Party men in uniform. ${ }^{58}$ The article therefore turned into more of a celebration of the piety of the Wehrmacht and the deep and honest belief in God on the part of the soldiers and the officers.

Another one of the few times when critique of the totalitarian systems was uttered in Credo during this period was with Pius XII's Christmas speech in 1941 when he spoke of the possibilities of a lasting and just peace. The Pope pointed out that in such a world order there was no room for 'intrusion into other nations' freedom, integrity, and security', 'open or masked oppression of ... the national minorities', the total war and a limitless armaments build-up, 'and persecution of religion and the churches. ${ }^{59}$ This could certainly be interpreted as a critique of all the totalitarian ideologies that are investigated in this article, even if it was quite general and not very specific.

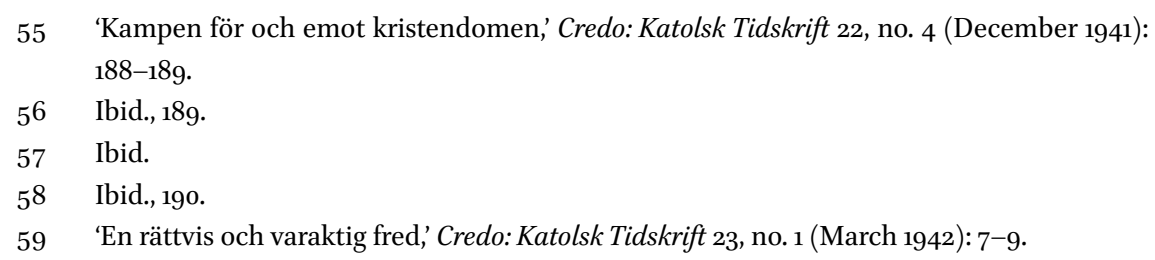


Not even at the end of the War did the Pope find it within his power and ability to condemn the Nazi crimes against the Jewish population in Europe. In the transcriptions of the Pope's speech that were published in Credo in September 1945 there is absolutely no mention of the mass murders of Jews. Instead it is once again the persecution of Catholic priests and laymen that is addressed and deplored. The Vatican consistently refused to accept any guilt whatsoever and stated that no one could hold the Church accountable for not revealing 'the real face of National Socialism, and the danger that it represented to human civilization. ${ }^{60}$ The Vatican, however, knew very well, through its many representatives in Germany, how the representatives of National Socialism treated those who did not agree with its ideological maxims and those that were considered racially inferior. It was also well informed, early during the War, about the fate that awaited the Jews and others who were deported to the concentration camps. ${ }^{61}$

The Pope did mention the concentration camps on one single occasion in the speeches that were reviewed in Credo, but it was not the Jewish experiences in those camps that occupied the Pope's mind or that were deplored. The Pope said: 'Together with the political prisoners now stream from the prisons, concentration camps, and forced labor camps, those priests and laymen, whose only crime was that they held on to Christ and to the faith of their ancestors and their courageously fulfilled duty as God's men.62 The Pope continued his lamentation by even giving the figure of the number of priests that had been interned in various camps, among them Dachau. In doing this he managed to name two groups of people that had been the victims of the Nazi mass murders and persecution, i.e. Catholic priests and political prisoners, but he (and Credo) left out the absolute majority of those targeted by National Socialism and who were the object (and subjects) of the Holocaust. Credo did not on one single occasion mention the millions of Jews that perished in the death and labor forced camps and elsewhere. The closest that Pius XII came to a post facto condemnation of the exterminations of Europe's Jewish population in Credo was when he proclaimed that: 'We continued our predecessors' work and never seized during the war - especially in our messages - to condemn the National Socialist doctrines, according to which they went so far as to apply the most refined scientific methods in order to torture most often completely

6o 'Den Helige Faderns radiotal vid krigets slut,' Credo: Katolsk Tidskrift 26, no. 3 (September 1945): 143 .

61 Phayer, The Catholic Church, 41-66; Zuccotti, Under His Very Windows, 202-214.

62 'Den Helige Faderns radiotal vid krigets slut,' Credo: Katolsk Tidskrift 26, no. 3 (September 1945): 144 . 
innocent people and subdue all Christian faith and law.' ${ }^{63}$ Notice the use of the phrase 'most often', which does indeed imply that torture of guilty people was somehow more acceptable.

The silence surrounding the fate of the Jews continued even during the following decade after the end of the War. Investigation of the content of Credo from 1945 to 1955 shows that no articles mentioning the Holocaust were published during this time.

\section{Credo and the Mussolini and Salazar regimes}

Credo's attitude towards these regimes was much more positive than towards National Socialism, and the obvious reason was that these rulers took much greater care to have a good relationship with the Church. When it was thought the Church's rights had been violated, however, Credo did publish critical articles. But the journal also published celebrations of Mussolini, Franco, and Salazar; this never happened in the case of National Socialism as we have seen above.

After Mussolini came to power in 1922 the situation improved for the Catholic Church in Italy, wrote Credo at the end of 1923. Because at that time the journal could tell its readers that 'Mussolini had held true to his promise to reinstate religious teaching in the schools' and that the education from now on would be based on Catholic Christianity. ${ }^{64}$ What Credo referred to was the Riforma Gentile, which took its name from Italy's Minister of Education at the time, Giovanni Gentile. ${ }^{65}$ It is 'with joy [that Italy] greets this new order' Credo reported and continued by saying that these steps were regarded 'as a step by the Fascist government towards liquidating the Catholic-hostile Italian layman law.'66 The Vatican namely saw this law as a result of the liberalism that had preceded Fascism, and it was thought to be hostile both to Catholicism and the family. ${ }^{67}$ This reaction seems to have been symptomatic, because Catholic journals in the United States received this news in a very similar fashion. ${ }^{68}$

63 Ibid.

64 'Från Credos torn,' Credo: Katolsk Tidskrift 4, no. 12 (December 1923): 328.

65 For more about the Church's attitude to this reform, see: Richard J. Wolff, 'Catholicism, Fascism and Italian Education from the Riforma Gentile to the Carta Della Scuola 19221939,' History of Education Quarterly 20, no. 1 (1980): 5-8.

66 'Från Credos torn,' Credo: Katolsk Tidskrift 5, no. 5 (May 1924): 115.

67 Wolff, 'Catholicism, Fascism and Italian Education,' 7.

68 John P. Diggins, 'American Catholics and Italian Fascism,' Journal of Contemporary History 2 , no. $4(1967): 5^{2}$. 
But nonetheless the Church could criticize the Fascist regime when it implemented policies that the Church thought to be a violation of its rights. This happened, for example, in the spring of 1928 when Credo reported two cases of Papal protest caused partly by Mussolini's decision to make Italian the mandatory language of education in the German-speaking South Tyrol, and partly because of the state's effort to monopolize the upbringing of the youth. Mussolini's reply to these protests was to declare that all Catholic youth organizations were to disband and that these youths should instead become members of Fascist youth movements. This struggle 'can have larger repercussions than we can imagine at the moment,' Credo warned ominously. 69

The relations between the Church and the government were repaired, however, and in February 1929 the Vatican state and the Italian Fascist government signed the so-called Lateran Treaty. The Treaty regulated the relationship between the signatories and solved old financial and territorial disputes between the Vatican and the Italian state. Credo published an article in connection with the signing of the Treaty and it was stated that the Treaty showed that Mussolini had realized the necessity of making peace with the Church and respecting its principles. ${ }^{70}$

In February 1933 Mussolini was celebrated in Credo for 'the good understanding between church and state that currently existed in Italy, which 'was expressed in a number of ways during the celebrations of the tenth anniversary of the Fascist regime.' The Catholic Action's diocese council then delivered a congratulatory address to the Fascist dictator. Mussolini was spoken of "in the words of Pius IX as "the man of divine providence" and the Church assured Mussolini of the unquestionable loyalty of the Piedmont Catholics.' The Church saw in Mussolini's 'restoration work .... an accomplishment that deserves complete recognition and unreserved appreciation from a Catholic point of view. ${ }^{71}$ Mussolini and Fascism were doing God's work on Earth, 'some men have been the wonderful instruments of God because of their talent, their bravery, their strength of character, their steadfastness of principle. Foremost

69 'Från Credos torn,' Credo: Katolsk Tidskrift 9, no. 5 (May 1928): 145; 'Från Credos torn,' Credo: Katolsk Tidskrift 12, no. 8 (August 1931): 221-222.

70 Alf Högh, 'Justitia et pax,' Credo: Katolsk Tidskrift 10, no. 4 (April 1929): 94-96. For more about this Treaty, c.f.: Godman, Hitler and the Vatican, 58-106, 172-199; Frank J. Coppa, 'Mussolini and the Concordat of 1929,' in Controversial Concordats: The Vatican's Relations with Napoleon, Mussolini, and Hitler (Washington: The Catholic University of America Press, 1999), 81-119.

71 'Kyrka och stat i Italien,' Credo: Katolsk Tidskrift 14, no. 2 (February 1933): 46. 
among them is Benito Mussolini.... The divine providence' had 'chosen Italy to be the messenger of peace and righteousness. 72

Not surprisingly, then, the Abyssinian War in 1935 would cause some problems for Credo and it devoted no less than three articles in November that year to the Italian invasion of this East African country. But Credo never explicitly condemned the war, and even published an overview of the official Catholic position on war in general that concluded that there were three types of war, all of which could very well be considered righteous under the appropriate circumstances. The closest the journal came to criticizing the war was when an article from a Polish Catholic journal was reviewed in Credo. This article said that one generally did not have the right to force civilization upon 'barbarians. ${ }^{73}$ Nevertheless, in February 1936, Credo published an article that complained about the Abyssinian government's deplorable treatment of the Catholic missionaries who had suffered greatly in the emergency of war. ${ }^{74}$

In January 1940 Credo published an article written in Norwegian entitled 'Den totalitære stat' [The Totalitarian State]. The article began with a condemnation of the totalitarian governments' wish to include man's whole reality, all areas of life (implicit in this criticism was that the governments thereby intruded on areas that belonged to the Church) - but it then changed tone and ended by arguing for embracing the totalitarian principle in the service of the Church. The challenges of this age that were facing the Church could not be met without a totalitarian mind-set, according to the author. Against the opponent's totalitarian will to subdue Christianity should be put the latter's totalitarian will to sacrifice and heroics. Against the opponent's totalitarian race creed and class spirit should be put the totalitarian universality of Christian love. ${ }^{75}$ It is clear that it was a completely different kind of totalitarianism that was being argued for here, but it was nonetheless a totalitarianism that required society's unquestionable submission.

Credo was positive towards dictatorship as long as it came in a form that was beneficial to the Church and Catholicism. This conclusion must be considered valid even though some soft criticism of the Mussolini government did appear on its pages. As in the American case the Italian Fascist government was

72 P. Agostino Gemelli, 'Katolicismen i det nutida Italien,' Credo: Katolsk Tidskrift 15, no. 3 (March 1934): 71-72.

73 'Kristendomen, påven och kriget,' Credo: Katolsk Tidskrift 16, no. 11 (November 1935): 253; 'Brottsligt,' Credo: Katolsk Tidskrift 16, no. 11 (November 1935): 256-257; Gustaf Armfelt, 'Kolonialkrig och katolsk moral,' Credo: Katolsk Tidskrift 17, no. 11 (November 1935): 258.

74 Kåre Skredsvik, 'Kyrkans mission in Abessinien,' Credo: Katolsk Tidskrift 18, no. 2 (February 1936): 43 .

75 Menzinger, 'Den totalitære stat,' $27-30$. 
regarded by Credo as being a Catholic state that, compared to Hitler's National Socialist state, looked very appealing. ${ }^{76}$

It is not only the articles about Mussolini that demonstrate this to be the case. One sees the same approach in how the Portuguese Catholic dictator António de Oliveira Salazar was described in Credo. Already in 1934 he was characterized by Gustaf Armfelt as a 'humble' person; as a hard working loner that did not surround himself with a 'coterie'; as a man from the country side that had been 'filled with disgust' for what he had seen as an elected representative; as a person who did not profit from his position; as a man that took care of the business of the state 'from his unassuming abode, from his office without secrets, like from a cell in a monastery.' Salazar was described as someone who was characterized by 'modesty personified, high sense of duty, free from ambition' and that had 'a deep Catholic acumen.' Salazar was thus described in a very positive light and in explicitly religious terms as a humble monk with a Catholic spirit sitting in a monastery.

In September 1940 yet another saluting of the Portuguese authoritarian dictatorship was published in Credo; an article that differentiated between this dictatorship, which was said to follow the 'authority principle' and the other dictatorships in Europe that was said to follow the 'totalitarian principle.' The former was not a 'caesarean authority, but a Christian' authority, it was concluded. ${ }^{77}$ The author tried to explain what that meant: 'in a totalitarian state the individual is subordinated to the leading principle, in the authoritarian state the human is ordered under the leading principle, whose purpose it is to be the ordering and gathering principle. ${ }^{78}$ Once again it was stressed that Salazar was a Catholic and that he therefore 'from his deep and sincere Catholic faith helped the Portuguese people to open their eyes to the importance of the eternal truth and the eternal values. ${ }^{19}$ Thus, what was contrasted against the authority principle was not fascism but totalitarianism in its secular form.

\section{Conclusion}

This article has investigated a subject that has never previously been researched, namely the attitude of the Swedish Catholic journal Credo to

\footnotetext{
76 Wentz, 'American Catholic Periodicals,' 406, 410.

77 Tove Rasmussen, 'Salazar - Portugal,' Credo: Katolsk Tidskrift 21, no. 9 (September 1940): 213 .

78 Ibid.

79 Ibid., 214-216.
} 
communism, Nazism, Fascism, Franco and Salazar. In the introduction two questions were presented which we can now satisfactorily give the answers to. These were: 1) What image of these ideologies and regimes did Credo purvey to its readers? and 2) What was the journal's attitude towards anti-Semitism and the discrimination, deportation, and mass murder of the European Jews before and during the Second World War?

In the part dealing with National Socialism we saw that Credo was indeed very critical against this ideology's tendency to subdue the Catholic Church to the state, and breaches of the concordat that were identified to have taken place were always strongly condemned. The criticism was always aimed at the regime's policies against Catholics, however, and the persecution of the Jews was never condemned, and hardly ever mentioned. Its readers could have easily been left with the impression that Catholics, not Jews, was the most persecuted group in Germany at the time, something that was of course never ever the case. Credo's readers also received somewhat mixed messages from the journal since it was not uncommon to find hostile anti-Semitic comments in Credo.

That said, the criticism of the Nazi regime's policy against the Catholic Church also shows that Credo was not afraid to criticize Hitler's government when it considered it important to do so. Thus one cannot, and this is very central, argue that the journal was silent about the persecution of the Jews because it was afraid to make the matter worse, or because members of the journal's editorial board had family in Germany and feared repercussions. Credo did in fact criticize National Socialism and the Hitler regime, sometimes quite seriously, but only when it came to crimes against Catholics or the Catholic Church. It did not take the side of all victims of the regime, which would perhaps have been the natural thing to do for an institution claiming to represent the one true faith and to hold the key to salvation for all humanity in its hand.

The difference between the attitude towards National Socialism and that towards Fascism could not have been greater, even if the Mussolini government also received some minor criticism when it undertook acts that were deemed negative for the Church. The criticism then, as always, centred on breaches of the Lateran Treaty and the Church's (in its own eyes) legitimate claims to power over the Italian people. If the regime intruded in this sphere the Church protested loudly. However, apart from these rare occasions the attitude towards Fascism was very positive and on occasion even overwhelmingly so. Mussolini was indeed described as God's instrument in world history; as a man that had brought Italy back to God and the true faith. This tendency was so strong that Credo did not even manage to issue a clear-cut condemnation of Italy's invasion of Abyssinia in 1935 . 
The Franco and Salazar regimes were also described in very positive terms. In fact, there was not a single critical article about either Franco or Salazar published in Credo. Franco was regarded as the man who had saved Catholic Spain from the godless communists, and while the communist crimes were detailed in the journal to shock the reader with the brutality of the republic, the nationalist side was described as piety materialized. Credo wrote of nationalist soldiers praying and of how God-fearing they were, and also related how religious life was blossoming once again in the Franco-controlled areas. Nothing was said of the brutal and violent acts perpetrated by Franco either during the civil war or during his reign in power. Salazar was depicted using an explicitly religious language comparing him to a monk who lived in complete modesty and piety. The fact that Salazar was a devout Catholic of course made Credo incapable of criticizing him or his regime, even though it was a brutal dictatorship that clamped down hard on dissenters. Instead Credo published articles that defended the idea of a Christian authoritarian dictatorship, and that such a system provided room for the individual to develop his or her potential. One could say that such a state was seen as a kind of worldly utopia by Credo.

With regard to communism, bolshevism was seen as being the creation of Satan himself, and the Soviet Union was even designated as being the 'Antichrist.' Another important dimension to the criticism of communism was the undisguised and even blatant anti-Semitism that was woven into it. Communism was intimately connected to 'the Jew' in the pages of Credo, and in connection with descriptions of atrocities by communists Credo often, and completely without reason, included anecdotal stories about Jews committing them. These anti-Semitic claims could even include theological ideas about the Jews, such as the one about Jews being responsible for deicide, i.e. the murder of Christ. We must therefore, when we evaluate the fact that Credo never defended the Jews against the crimes committed by the Hitler regime or even reminded its readers of the unimaginable suffering that the Jewish people were going through in Europe before and during the War, be aware of the importance of the Catholic theological predisposition towards anti-Semitism.

The results of this case study analysis have been a mixture of both the surprising and the expected. Further investigations of similar journals in other countries will no doubt yield interesting and worthwhile results as well. 